\title{
Meritocracy ANd POPULISM - IS THERE A CONNECTION?
}

\author{
Erzsébet Bukodi \\ Department of Social Policy and Intervention, \\ Nuffield College \\ University of Oxford \\ Erzsebet.bukodi@nuffield.ox.ac.uk \\ John H. Goldthorpe \\ Nuffield College \\ University of Oxford \\ John.goldthorpe@nuffield.ox.ac.uk
}

JANUARY 2022 


\section{ABSTRACT}

In three recent critiques of meritocracy - Markovits (2019), Sandel (2020) and Goodhart (2020)

- the argument is advanced that the failing pursuit of an education-based meritocracy by mainstream political parties, in the context of persisting meritocratic discourse, has led to status discontents that readily translate into support for populist movements and parties. We aim to show that recent research, to which the authors in question make little reference, can in fact provide more direct backing for their argument than they themselves provide. There is increasingly strong evidence that populist support is grounded in status concerns - is an expression of status rather than of class politics. Evidence that status discontents derive from the co-existence of meritocratic discourse with a failed meritocracy is scarcer and of a less compelling kind. But some research findings highly consistent with such a view can be cited, and serve to show the direction that further research needs to take if a meritocracy-populism connection is to be more firmly established. We end by observing that insofar as this should prove the case, the policy and political issues that would arise would be far-reaching, and attempts to move beyond the present situation could be expected to lead to political conflict with uncertain outcomes. Conditions favourable to populism could well continue. 


\section{INTRODUCTION}

Over the last decade or so, critiques of the idea and the practice of 'meritocracy' in the western world have regularly appeared (e.g. Goldthorpe and Jackson, 2008; MacNamee and Miller, 2009; Bloodworth, 2016; Littler, 2018). Although these critiques are written from differing disciplinary positions, two points recur. First, very limited progress has in fact been made towards the creation of a genuinely meritocratic social order, despite this being a widely accepted political objective. The 'myth of meritocracy' is a common phrase. Second, the meritocratic discourse that nonetheless prevails carries damaging implications for those who have not achieved 'success'. Three contributions in this same vein have recently appeared, which, however, include a further contention that is of potentially large importance. The books of Markovits, a lawyer and economist (2019), of Sandel, a political and social philosopher (2020), and of Goodhart, a senior think-tank figure (2020) share in the view that a connection exists between the pursuit of meritocracy and the rise of populism, and with status discontents being the crucial mediating factor. This argument is developed, with reference chiefly to the US and the UK, ${ }^{1}$ in a highly persuasive style. But, despite the citation of much social science literature in other respects, it is not itself provided with a grounding in empirical research of any very direct kind.

In this paper, we do not present new research findings relevant to the claim of a meritocracypopulism connection. Rather, having first set out the case that Markovits, Sandel and Goodhart

\footnotetext{
${ }^{1}$ Markovits and Sandel focus on the US but make frequent reference to the UK, and the UK edition of Markovits' book has an Appendix devoted to the UK. These two authors are, as the titles of their books indicate, concerned quite specifically with meritocracy and its problems. In some contrast, Goodhart focuses on the UK, though with frequent reference to the US, and his most immediate concern is with the changing importance and evaluation of different kinds of work - 'head, hands and heart'. But the implications in this regard of the pursuit of meritocracy is a constant underlying theme.
} 
make out for such a connection, we seek to show that there is existing research, much of it very recent, that is of relevance. As regards one side of their argument - that it is the changing expression of status relations that is a major source of populist support - the results of this research would appear increasingly confirmatory. As regards the other side - that it is the coexistence of meritocratic failure with meritocratic discourse that is a major source of status discontents - the evidence available is more limited and of a less compelling kind. However, at least one piece of research has produced results that are highly consistent with such a view, and brings into sharper focus the questions that call for further examination if a meritocracypopulism connection is to be more securely established. We end with some discussion of the policy and political issues that would arise if the position that Markovits, Sandel and Goodhart take up were to be further validated. These we would see as far-reaching, and attempts to move beyond the present situation would entail political conflict with an uncertain outcome. Conditions favourable to populism could well continue.

\section{THE CASE MADE OUT FOR A MERITOCRACY-POPULISM CONNECTION}

Markovits, Sandel and Goodhart are in general agreement with each other and with earlier authors that, in the US and the UK at least, little movement is apparent towards a meritocracy, in the sense of a distinctively open form of society in which access to leading, better-rewarded positions results from individuals' demonstrated capacity, and is independent of the accidents of their birth. And this is so despite the creation of such a meritocracy being - as they amply document - a goal that mainstream political parties of the left and right alike have for some time explicitly adopted. Their explanation for this failure is on the following lines. 
Merit is not 'a natural or universal virtue' (Markovits, 2019: 73). Rather, what counts as, and is valued as, merit in a society is highly context-dependent. In a hunter-gatherer society, merit and its rewards would derive from prowess in the chase and field craft. In modern, technologically advanced societies, with economies and organisational procedures that are increasingly 'knowledge-based', labour markets are so constructed that merit becomes equated with cognitive ability, as this is developed and certified within the educational system - and especially at its higher academic rather than vocational levels. It is then this system that serves as the key sorting mechanism through which individuals are allocated to social positions with differing levels of reward, material and symbolic.

However, the problem arises that cognitive ability is developed not only within the educational system but also - and, on all the evidence, more importantly - within the family. Thus, as Sandel observes (2020: 121), it is 'the institution of the family' that crucially compromises the meritocratic project 'of giving everyone an equal chance'. Those who in one generation have gained advantaged positions through merit, as achieved via education, will seek to deploy their superior resources so as to enable their offspring to follow a similar route, and as inequalities determined by what is taken to be merit increase, the fear of educational failure and consequent downward social mobility intensifies (cf. Ehrenreich, 1989). The 'concerted cultivation' of children (cf. Lareau, 2003) thus becomes an overriding concern. More advantaged parents exploit their own educational experience and the cultural resources deriving from it in order to ensure that their children's natural endowments find their fullest expression, and in regard not only to cognitive ability but also to other attributes relevant to the application of this ability, such as industriousness and perseverance (Markovits, 2019: 14756; Sandel, 2020: 12-13, 177-9). Moreover, as well as in this way furthering their children's 
educational careers, and in turn their labour market prospects, more advantaged parents are ready enough also to apply their economic and social resources to these same ends. For example, in gaining their children access to elite schools and universities, and to social circles and networks through which favourable employment opportunities are likely to arise.

Thus, although the application of meritocratic principles may have helped to increase equality of opportunity in class-bound societies of the past, 'the meritocratic inheritance now drives a wedge between meritocracy and opportunity' (Markovits, 2019: 147). In turn, any increase in social mobility that was previously achieved is lost because of the growing tendency for what counts as merit to be regularly transmitted across generations, resulting in the creation of a virtual cognitive caste (Markovits, 2019: 260-1; cf. Sandel, 2020: 168-9). Or, in Goodhart's words (2020: 8), 'mobility inevitably slows when "smart produces smart"'.2

Up to this point, nothing much is added to what is already well established. The failure of an education-based meritocracy to emerge and the reasons for this failure have for long been the subject of sociological research and analysis. Halsey (1977: 184) was already observing that, through the influence of the family, 'ascriptive forces find ways of expressing themselves as achievement', and research pursuing and developing this insight has continued to the present (see e.g. Bukodi and Goldthorpe, 2019). Nor is the next step in the three authors' case all that new either: that is, the claim that the discourse of meritocracy and 'the rhetoric of rising'

\footnotetext{
2 The question of the size and composition of the meritocratic or cognitive elite leads to some difficulties, especially with Markovits. To begin with, he appears to equate this elite with the top $1 \%$ of households in terms of disposable income, though with a 'penumbra' of the next highest $5-10 \%$. Elsewhere, however, in seeking to further characterise his elite, he refers (e.g. 2019: 47-8, 86, 117-8, 182-3) to the much larger groupings of the top quintile or quartile of earners or simply to graduates. Sandel and Goodhart appear more consistent in equating the meritocratic elite with higher-level managers and professionals with graduate qualifications.
} 
necessarily carry damaging psychological consequences for those who do not get ahead, and thus provides grounds for moral objections to the very idea of meritocracy. Here, the main recourse is to Michael Young, and in particular (Markovits, 2019: 258-9; Sandel, 2020: 30-1, 116, 152; Goodhart, 2020: 75-7) to Young's repeated and increasingly angry attempts (1994, 2001, 2006) to get across, to politicians especially, that his dystopian fantasy, The Rise of the Meritocracy (1958), was intended not as an endorsement of meritocracy but rather as a warning against its unremitting pursuit. What is emphasised, following Young, is that insofar as success is regarded as merited, as the result of ability and effort, those who succeed are encouraged to believe that their advantaged positions in society are well-deserved 'meritocratic hubris' - regardless of the role played by sheer luck both in having talent and the opportunity to use it (cf. Frank, 2016). At the same time, those who do not succeed are left to draw the unforgiving conclusion that they are lacking in ability and/or idle, and thus undeserving. In Young's own words, which Sandel (2020: 152) quotes, 'It is hard indeed in a society that makes so much of merit to be judged as having none. No underclass has ever been left as morally naked as that.'

However, what is then new in the work of Markovits, Sandel and Goodhart alike is the idea though in fact one imaginatively anticipated by Young - that the adverse psychological effects on those who are taken to be lacking in merit, in a society where meritocratic discourse prevails, have political consequences. Individuals who are so demeaned, they maintain, become open to the appeals of populist movements and parties, characterised by a hostility 
to the elites that an envisaged, but in fact still largely sham, meritocracy throws up, to the views these elites express, and to the institutions they dominate. ${ }^{3}$

In more detail, this new claim starts out from a consideration of what has followed from the acceptance by mainstream parties of an education-based meritocracy as a prime political objective. First of all, it has been assumed - mistakenly - that in such a meritocracy social mobility will increase and that this will in turn serve as the solution to the problem of social inequality (see esp. Sandel, 2002: 69-71, 85-7). Thus, for Tony Blair, not only were his priorities 'education, education, education' but, further (speech, June 2002), he saw mobility as being, in itself, 'the great force for social equality in dynamic market economies'; likewise, Hilary Clinton (speech, September 2016) wanted 'a true meritocracy' because she was 'tired of inequality'; and Theresa May (speech, September 2016) proposed overcoming the 'injustices' of social inequality through a meritocracy based on a widening of educational opportunity that would promote mobility. Second, while questions of class inequalities of condition were in this way effectively sidelined, even on the left, questions of racial, ethnic and gender inequality came to be given a leading importance. In the UK, New Labour set up the Equality and Human Rights Commission to deal with these and various other inequalities - from which, however, inequalities of class were excluded. Third, the idea inherent in the discourse of meritocracy that individuals' social destinies ultimately lie in their own hands - are their personal responsibility - was made increasingly explicit, and given an underlying moral force. Not only were the 'smart' valorised as against the 'dumb' but further the 'makers' were morally

\footnotetext{
${ }^{3}$ Young's fantasy ends with the overthrow of the meritocracy as the result of an alliance between the Conservative Party, favouring a return to hereditary principles, and the members of a newly formed Populist Convention, among whom technicians and women were prominent. Some suggestion that 'political' meritocracy - the domination of parties and governments by the highly educated - could lead to populist reaction can be found in Bovens and Wille (2017).
} 
contrasted with the 'takers', the 'strivers' with the 'skivers', the 'grafters' with the 'shirkers'. In the US, Obama repeatedly asserted that 'You can make it if you try' (Markovits, 2019: 61-2; Sandel, 2020: 34-5). An example from the UK would be David Cameron on his favourite theme of 'the Aspiration Nation'. Claiming to be engaged in a battle against those who were not hard workers, and against socialists who excused low expectations and blamed social disadvantage, Cameron declared 'That's who we're fighting against, and we know who we are fighting for: for all those who work hard and want to get on' (Conservative Party Conference speech, 2012).

Against this background, the argument then goes, those who have not succeeded in supposedly meritocratic terms not only feel economically 'left behind' and socially marginalised but also deceived and disparaged. For these people, as Sandel puts it (2020: 734), either an education-based meritocracy has not lived up to its promise - a greater equality of opportunity has not in fact been created - or, if it has, they have lost out and it is their own fault. And a further source of discontent among the losers is the belief that while other forms of inequality and disadvantage have become a focus of concern among political elites, the inequalities that blight their lives - that curtail their opportunities - are ignored because they are people who 'do not count'. A crucial sociopolitical shift thus occurs. Although purely economic, class discontents remain, they become transmuted, and at the same time widened, into status discontents (Goodhart, 2020: 3-4; Sandel, 2020: 115). Disaffection arises among a broad swathe of the 'undeserving' essentially as a result of their status derogation. Their material disadvantages and problems remain unalleviated but at the same time they experience a growing separation, in terms of their perceived social and human worth, from those of high ability - or at least from those so certified academically - who, they feel, now look down on them from the higher levels of the status hierarchy. 
For the status deprived, the appeals of populism are then rather obvious, and especially as compared with what Goodhart (2020: 149) calls the 'double liberalism' - both economic and social - as espoused by New Labour in the UK and the New Democrats in the US in their search for greater electoral support from among meritocratic winners. For the losers, nativism, nationalism and anti-elitism provide attractive bases of a form of identity politics through which they may regain some degree of self-esteem and pride or, as Markovits suggests, that can at least serve as an 'anesthesia' or 'narcotic' that 'deadens the internalized shame of nominally justified social and economic exclusion'. And from this point of view, as Markovits goes on to observe (2019: 63-5), populism has to be seen not simply as 'a spontaneous eruption of malevolent resentment' but rather as 'a natural and even apt reaction to extreme meritocratic inequality' - in status as well as in material well-being. In similar vein, Sandel and Goodhart concur in regarding the 2016 Brexit vote in the UK and Trump's 2016 Presidential victory in the US as alike resulting, in significant part, from populist protest voting that was an understandable response to 'a profound status shift' in favour of the cognitive elite (Goodhart, 2020: 28). What was expressed was a 'galling sense that those who stood astride the hierarchy of merit looked down with disdain on those they considered less accomplished than themselves' (Sandel, 2020: 72).

As an example of 'the view from above', both Markovits (2019: 61) and Sandel (2020: 118) quote Hilary Clinton's remark during the 2016 US presidential campaign that half of Trump's supporters were a bigoted 'basket of deplorables' who were 'racist, sexist, homophobic, xenophobic, Islamophobic, you name it'. An example in the British case would be Prime Minister Gordon Brown's accidentally recorded comment, when campaigning at the 2010 General Election, that a working-class woman was a bigot because she challenged him over 
East European immigrants 'flocking into' Britain. The critical stance taken in regard to such instances is not intended to deny bigotry. It centres on the lack of empathy that is revealed the 'empathy wall' (Hochschild, 2016) - and on the disregard of the question of why bigotry should exist.

The case thus made out for a meritocracy-populism connection has some evident plausibility, and the authors in question write with panache. But, as earlier noted, there are in effect two sides to their case, both of which call for greater empirical support. On the one side, status is seen as transcending class as the social basis of populism; on the other side, status concerns are seen as deriving from failed political attempts to create an education-based meritocracy while meritocratic discourse remains prevalent. In short, if meritocracy is a source of populism, status relations are the crucial linking, or mediating, factor. How far can presently available evidence from social research give support to these claims? We consider in turn the two links in the chain of argument.

\section{STATUS AND POPULISM}

Over the last two decades, sociologists in the US and the UK alike (see e.g. Hechter, 2004; Chan and Goldthorpe, 2007; Chan, 2010; Goldthorpe, 2012; Ridgeway, 2014) have shown an increasing concern with the analytical potential of Max Weber's distinction (1922/1968, vol. 1: 926-40) between class and status - for long discussed in sociological texts but little exploited in empirical research. Class refers to the positions individuals hold in the social relations of economic life - in labour markets and workplaces. Status refers to their positions in relations of distinction or prestige as expressed primarily through differential association in the more 
intimate aspects of social life, in particular commensality and connubium: status equals are those who eat together and sleep together.

As regards the political implications of the distinction between class and status, a finding of initial relevance is one reported by Chan and Goldthorpe (2007), using a social status scale (Chan and Goldthorpe, 2004) that, following Weber, is based on differential association specifically, on the occupational structure of close friendship - and the EGP class schema (Erikson, Goldthorpe and Portocarero, 1979), based on employment relations (both reproduced in Appendix 1). Analysing data from the British Social Attitudes Survey they then show that, with income and education also being taken into account, individuals' class and status are associated with sociopolitical attitudes in quite differing ways. In particular - see Figure 1, derived from their work - a marked contrast exists in the case of left-right and libertarian-authoritarian attitudes, as measured by standard scales (Evans, Heath and Lalljee, 1996). Left-right attitudes are strongly associated with class but weakly, if at all, with status. Libertarian-authoritarian attitudes are strongly associated with status but no significant association exists with class. ${ }^{4}$ A clear indication is thus given that individuals of relatively low status could, across some range of class positions, be potential recruits to socially conservative populist movements or parties claiming to uphold national culture and its values, while showing hostility towards social practices or groupings seen as deviant from and disruptive of

\footnotetext{
${ }^{4}$ An association also exists between income and left-right attitudes - on lines that might be expected and between education and libertarian-authoritarian attitudes. The relation between low education and low status will be taken up in our subsequent discussion of further relevant research.
} 
these values. ${ }^{5}$ Three further pieces of research can then be noted that treat the politics of social status more directly.

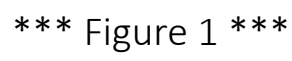

Gidron and Hall (2017, 2020) examine the relationship between what they refer to as 'subjective' social status and support for populist parties across a wide range of European countries for which comparative survey data are available. From multivariate analyses, they find a strong association between low levels of subjective status and voting for populist parties, while controlling for respondents' income and education. Further analyses that they report then indicate that individuals who support populist parties, and right-wing ones especially, are less motivated by economic and redistributional concerns than by concerns over their marginalisation and lack of social recognition. They are thus highly responsive to populist attacks on the sociocultural effects of globalisation and mass immigration and on the elites they see as complicit in, and benefiting from, these developments. These findings would thus appear much in line with the arguments advanced by Markovits, Sandel and Goodhart to the effect that it is primarily status concerns that fuel populist politics.

However, while Gidron and Hall's work is impressive in its coverage, questions have to be raised over their concept of subjective status and their measurement of it through a version of the MacArthur scale. What this involves is simply individuals placing themselves on a 10-rung

\footnotetext{
${ }^{5}$ It is in this regard important to observe that although individuals' class and status positions are associated, the association is only modest (see Chan and Goldthorpe, 2004: Tables 2 and A1). Thus, proprietors and managers in small-scale manufacturing and also in construction, transport and services have lower status than even quasi-professionals, and not greatly above that of many manual workers. That is to say, while they are in different class positions to the latter in terms of their employment relations, they differ rather little from them in their patterns of association as indicated by the occupations of their close friends.
} 
'social ladder' that is given no specific characterisation. Great uncertainty must then arise over how individuals' assessments of where they stand on such a ladder are to be interpreted, and in particular over how far these assessments relate to their 'objective' status in the Weberian sense - which Markovits, Sandel and Goodhart would in general appear to adopt. There is in fact recent evidence (Evans, 2022) that in making their placements on the ladder individuals tend to think more of where they stand within the distributions of income or wealth rather than within a status hierarchy. ${ }^{6}$

Fortunately, though, two further studies are now available, both of which, in seeking to capture status positions in Weberian terms, use the Chan-Goldthorpe status scale previously referred to. And these studies, as it turns out, report findings that are broadly consistent with those of Gidron and Hall.

First, Carella and Ford (2020) report on research into the sources of electoral support for the United Kingdom Independence Party (UKIP), prior to the EU Referendum of 2016 - this having been a matter of some disagreement between Ford and Goodwin $(2014,2016)$ and Evans and Mellon (2016). Ford and Goodwin maintained (2014: 270) that UKIP's 'distinctive social base' was in the working class and in particular 'among older blue-collar workers with little education and few skills', who felt economically marginalised by deindustrialisation and politically marginalised by the Labour Party's increasing focus on 'the centre ground'. However, Evans and Mellon argued - and presented evidence to show - that UKIP's support was wider than

\footnotetext{
${ }^{6}$ Evans (2022) also notes that when first used by social scientists the scale was interpreted as one of 'class identity' rather than of subjective social status, and further that when applied in medical and psychological research, the common practice is to make it clear to subjects that the ladder can be taken as one of 'money', 'education' or 'job respect'. For a critical review of concepts and measurement of status in recent social research, see Carella (2021).
} 
this, comprising not only working-class defectors from Labour but also significant numbers drawn from the 'petty bourgeoisie' of small proprietors and employers and self-employed artisans and also from technicians, supervisors and lower-level managers, who were previously Conservative voters. What brought these groups together, from differing class positions, was their authoritarian, socially conservative attitudes and, in particular, their concern over rising immigration, especially from EU 'accession' countries after 2004.

Carella and Ford then provide a convincing resolution of this issue. Drawing on data from the 2015 sweep of the UK Understanding Society Survey, they run logistic regression models with party preference as the dependent variable, in which they include individuals' status, according to the Chan-Goldthorpe scale, along with measures of their class (National Statistics Socioeconomic Classification), education and income. Their analyses reveal - see Figure 2 that a strong negative association exists between status and UKIP preference: i.e. the lower an individual's status, the more likely he or she is to favour UKIP. But no significant association appears between class and UKIP preference. A negative, though not entirely monotonic, association is also shown (Carella and Ford, 2020: Table 3) between educational level and UKIP preference - the main contrast being between graduates, who are most resistant to UKIP, and the rest. ${ }^{7}$ Status is, however, quite clearly of independent importance. In short, while Evans and Mellon were correct in claiming that UKIP voting was far from being limited to the working class, UKIP appears as more than a party dependent on some ad hoc cross-class coalition or on an alliance of individuals who just happened to hold similar sociopolitical attitudes. Its support had a social structural basis in the lower ranges of the status hierarchy.

\footnotetext{
${ }^{7}$ UKIP support proves to be somewhat stronger among those with lower secondary qualifications than among those with no qualifications - a further indication that such support should not be seen as limited to 'blue-collar workers with little education and low skills'.
} 
Turning to European Social Survey data, Carella and Ford then extend their analyses to nine other European countries with electorally significant right-wing populist parties. They find that, in a very similar way as in the UK, support for such parties is more strongly associated with status than with class. And for all nine countries, and in line with the Chan-Goldthorpe results presented in Figure 1, they find that while class is highly predictive of attitudes relating to redistribution, it is status, and not class, that is predictive of attitudes relating to immigration.

Second, Chan et al. (2020) follow Carella and Ford in exploiting data from the UK Understanding Society Survey but for a later period at around the time of the Brexit vote of 2016, when a question was included identical to that asked in the referendum. On this basis, they seek to evaluate two narratives concerning Brexit - the movement for which they take to be populist in inspiration. One narrative sees Brexit as a revolt of the economically disadvantaged, the other sees Brexit as being more socioculturally influenced and as expressing a resurgence of an authoritative nativism and nationalism. In the present context, it is the relative importance of class and status in Brexit support that is of central interest. As Chan et al. observe, if Brexit was primarily driven by economic issues, then Brexit support should be mainly stratified by class; but if a reassertion of national identity and associated values was chiefly involved, then stratification by status should be more apparent.

Chan et al. undertake logistic regression modelling on much the same lines as Carella and Ford but with Brexit support as the dependent variable. The results they produce prove to be highly consistent with those reported by the latter on preference for UKIP - see Figure 3. There is no significant association between class and favouring Brexit but a pro-Brexit position is associated with low status. Brexit support is also stronger among those with lower educational 
levels - though again, as in Carella and Ford's analyses, not entirely monotonically, and with the contrast between graduates and the rest being most marked (Chan et al., 2020: Table 1). Again, though, the independent effect of status remains substantial.

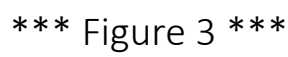

Further, Chan et al. find (2020: Figure 5) that an association exists between individuals' positions on Brexit and their patterns of cultural consumption that is likewise independent of their educational level. Those who are cultural omnivores, consuming many different genres of music and the visual arts, show a strong tendency to oppose Brexit, while those who are cultural univores, consuming popular genres only, show a similarly strong tendency to favour Brexit. And since it has been elsewhere established (Chan, 2010, 2019) that these differing patterns of cultural consumption are associated not with class but with status, and also with differing value orientations on a 'local-cosmopolitan' dimension (Merton, 1957: ch. 10), the view of Brexit as an expression of status politics is reinforced.

In sum, strong evidence has of late emerged to underwrite the claims of Markovits, Sandel and Goodhart that, insofar as populism has a grounding in social stratification, this lies in status rather than in class relations. ${ }^{8}$ And, it may be added, the research reviewed above points to a way of making good shortcomings evident in other recent analyses of populist movements.

\footnotetext{
${ }^{8}$ Among those who have worked with the concept of 'subjective' status, as measured by the MacArthur scale, the issue has arisen of whether, in accounting for support for populism, it is low status per se or a decline in status, especially among the working class, that is chiefly important. Gidron and Hall (2017) tend to favour the latter view, but Oesch and Vigna (2021) question on empirical grounds whether any decline has occurred. Nolan and Weisstanner (2020) claim that it has occurred in 'relative' but not 'absolute' terms, while Richards, Heath and Carl (2020) argue that subjective status is primarily consequential in its interaction with objective 'socioeconomic' status. We do not find these debates all that illuminating, and they reinforce our previously expressed doubts (Bukodi, Dex and Goldthorpe, 2011) about the value of 'synthetic' scales of status, whether subjectively or objectively considered.
} 
For example, Inglehart and Norris (2017) and Norris and Inglehart (2019), in advancing a general theory of the sources of populism, speak of a shift from class politics to value politics - the latter turning on a socially conservative and authoritarian 'cultural backlash' against the values of 'post-materialism'. But this shift appears to have no social basis. It is seen as being related only to some sense of a decline in economic and physical security, felt especially among the poorly educated members of older birth cohorts. Likewise, Fieldhouse et al. (2020: 181-4), using British Election Study data to analyse support for Brexit, link this with low education and older age, and then introduce authoritarian as opposed to libertarian values as, it would seem, a mediating variable. However, given that the value divide that the authors in question invoke is clearly associated with status, as demonstrated by Chan and Goldthorpe (2007), thinking in terms of a shift not from class-based to value politics but from class-based to status-based politics could be regarded as more revealing. Bringing status into the analysis, at both a theoretical and empirical level, would mean that differing value orientations would appear less 'free floating' and could be seen to have a specific social grounding and rationale. It may also be noted that the claim that support for populist movements and parties is concentrated in the poorly educated in older birth cohorts implies that, as Norris and Inglehart put it (2019: 16), 'the cultural cleavage in the electorate is likely to fade over time through demographic trends'. But, given that status relations are also a factor in populist support, over and above

\footnotetext{
Status orders in the Weberian sense, expressed in differential association, do not appear subject to any very rapid change, but what can change, and would seem most relevant in the present context, is the expression of status inferiority or superiority. Some decades ago, there was much discussion of the 'decline of deference' on the part of those in inferior status positions towards their superiors. Today, what Markovits, Sandel and Goodhart propose is that meritocratic discourse encourages a greater tendency for the derogation by those in superior positions of those below them - thus provoking a response favourable to populism. As Weber indeed recognised, status orders are always likely to be in differing degree accepted or subject to challenge or reassertion.
} 
education and age, the appeals of populism could prove persistent - as well as for other reasons that we suggest in our conclusions.

\section{MERITOCRACY AND STATUS}

Evidence relevant to a possible link between meritocracy, in practice and discourse, and status discontents is far more difficult to come by than that which points, rather convincingly, to a link between such discontents and support for populism. In the British case, there is, however, one body of evidence that could at least be thought highly suggestive. This comes from focus groups organised by Mattinson (2020) in three historic Labour strongholds, Accrington, Darlington and Stoke-on-Trent, that were parts of the 'Red Wall' that collapsed in the 2019 General Election when Boris Johnson, campaigning with the slogan 'Get Brexit done', led the Conservatives to a sweeping victory. The men and women selected for inclusion in the focus groups were all former Labour voters who, in 2019, had switched to the Conservatives, and Mattison's main concern was to investigate their motivations for so doing. Participants were also selected so as to fall into the Market Research Society's C2, D and E 'social grades'. This is not in itself very informative as regards either their class or status. However, from the occupations that are mentioned - bricklayer, lorry driver, taxi driver, carer, catering worker, hairdresser, shopkeeper, café proprietor, works technician, site manager - it would seem that the large majority of those involved would be in the lower ranges of the Chan-Goldthorpe status scale.

Reservations must exist about evidence derived from focus groups on several grounds; we would not see it as being of the same reliability as that obtained from well-designed survey 
research. ${ }^{9}$ It should also be noted that issues of meritocracy did not, at least in any direct way, appear to figure in the focus group discussions. Nonetheless, accepting Mattinson's interpretation of these discussions, themes emerge that are remarkably consonant with the arguments of Markovits, Sandel and Goodhart to the effect that a failed meritocracy, in coexistence with meritocratic discourse de haut en bas, are prime sources of hurt and anger, in search of political expression, among those in the lower levels of the status hierarchy.

First, focus group participants showed a strong awareness of the lack of opportunity in their communities, especially for young people, and whether in education, training or employment. Previously, when local industries had flourished, apprenticeships and other forms of training were readily available leading to jobs that, even if demanding and sometimes dangerous, were secure, relatively well paid, and 'respected'. All this, it was felt, had been lost - had in fact been 'taken away' - with traditional skills being made worthless. Gest, Reny and Mayer (2018) have argued that what they call 'nostalgic deprivation', and an associated sense of status under threat, are important drivers of support for 'the radical right'. They also remark (2018: 1699) that such nostalgia 'is a matter of perception and may not be objectively real'. However, in the case of the localities in question, the central facts of their recent economic and social history can leave little doubt that nostalgia was indeed well-grounded.

\footnotetext{
${ }^{9}$ There is no guarantee that the views expressed by participants in focus groups are representative of those prevailing among the collectivities from which they are drawn, and to which generalisations may then tend, if only implicitly, to be made; and simply insisting that it is qualitative research that is being undertaken (Mattinson, 2020: 10) in no way overcomes this problem. Further, it is difficult to know how far views emerging from a focus group are a - possibly ephemeral - product of the social dynamics of the group, and including of its 'mediation', rather than representing pre-existing elements of participants' 'mental furniture'.
} 
In turn, strong resentment was shown by the men and women in the focus groups of any suggestion that their present circumstances were of their own making - that they came about through their own individual shortcomings. People in their communities, they emphasised, had always believed in hard work, and still did work hard - but now mostly in low-skill, insecure, poorly paid, and sometimes demeaning jobs, simply because there was no alternative (Mattinson, 2020: 22-9, 61-6, 85-6). As said, questions of meritocracy did not directly arise in the focus groups. But it would seem reasonable to suppose that had the idea been suggested to participants that a meritocracy rewarding ability and effort, and founded on equality of opportunity, existed or was being created in their communities, this would have been met with some incredulity, to put it no more strongly.

Second, and still more significantly, a critical view emerged within the focus groups of those who might be regarded as the cognitive elite - the meritocratic winners - or, at all events, if this elite could be equated with graduates. Degrees were regarded as appropriate qualifications for established professionals, such as doctors or lawyers, but otherwise doubts were expressed about the social, if not the individual, value of the increase in what one participant called 'fancy degrees'. Further, people with degrees - and young people especially with limited life experience - were thought to 'look down' on 'little people', lacking in educational accomplishments. ${ }^{10}$ Resentment indeed appeared most marked where it was felt that either an intellectual or a moral ascendancy was being claimed. In the case of Brexit,

\footnotetext{
${ }^{10}$ It should be noted that, given the information on their occupations as referred to in the text above, it would be mistaken to suppose that focus group participants were in general educationally unqualified; some proportion would certainly have had qualifications at least of a vocational kind. As earlier observed - though a point often disregarded - individuals with no qualifications appear to be somewhat less likely supporters of populist politics than those with qualifications at a lower secondary level.
} 
which most of those in the focus groups had supported, anger was expressed over graduate Remainers implying that Leavers were 'misguided', if not 'ignorant' or 'stupid'. And strong objections were made to accusations of 'racism' being levelled against those who questioned uncontrolled immigration on the basis of direct experience of its impact on their communities. Politically, these views then translated into a deep disillusionment with the Labour Party. This was seen as now dominated by graduate metropolitan elites - whether centrist Blairites or leftist Corbynites. These elites, it was felt, were obsessed with political correctness, and more concerned with telling the people they were supposed to represent that they were 'wrong' than with trying to understand the conditions under which they were living and their responses to these conditions (Mattinson, 2020: 7-8, 47-8, 88-9, 91-3, 128-31, 227-8). ${ }^{11}$

In sum, what most strikingly emerges is that although members of the focus groups were drawn from communities of 'the left behind', where economic disadvantage was prevalent and strongly felt, the social division of which these men and women appeared most conscious was not a class division but what could be better understood as a status division. 'Us' and 'them' referred not, as historically, to workers and bosses but to those not having higher education and those who were so favoured. And discontent and antagonism arose not over conflicting economic interests but over the way in which the higher educated were seen as taking the status conferred on them by their certified merit as a basis for discounting, if not for demeaning and reproving, those they supposed their inferiors.

\footnotetext{
${ }^{11}$ Although the incident was not apparently mentioned in the focus groups, the 'rejection of Islington' - the London suburb associated with both Blair and Corbyn - was more generally illustrated at the time of the Rochester and Strood by-election of 2014. Emily Thornberry, Labour MP for Islington South and Finsbury, while campaigning, posted a mocking photograph of a white van parked outside a house bedecked with St George's flags. The house-owner, a second-hand car dealer, gained widespread support in denouncing Mrs Thornberry as 'a snob'. The by-election was won by UKIP with Labour coming a poor third; and Mrs Thornberry was sacked from her position in the shadow cabinet.
} 
What is then pointed to is the potential importance of further, appropriately designed, survey research that could more thoroughly test the idea that the persistent, but failing, pursuit of an education-based meritocracy, in a context in which, to revert to Young's phrase, 'so much is made of merit', has led to a ready responsiveness to populism - and not only among disaffected former Labour voters but, more generally, among all those at the lower levels of the status hierarchy for whom the benefits of such a meritocracy have been little apparent. Such research would be of obvious academic interest; but, given the importance that mainstream parties of the right and left have alike attached, and continue to attach, to the promotion of the idea of meritocracy, it could also, as discussed further below, carry potentially large implications for future policy and politics.

\section{DISCUSSION AND CONCLUSIONS}

Markovits, Sandel and Goodhart follow earlier critics in maintaining that little progress has been made, or is indeed likely to be made, in transforming modern societies into educationbased meritocracies; and this view, it can be said, is very largely underwritten in the social science literature. Socially grounded inequalities in educational attainment and in relative chances of social mobility have proved highly resistant to change, despite the range of policies that have been aimed at their reduction. The concerns of the authors in question are, however, normative as well as empirical. They see the very idea of meritocracy as being one that is open to serious question both morally and politically. Morally, it is unclear that the talented do 'merit' the extent of the rewards that, at least in capitalist market economies, they receive, if only because of the part played by luck - by natural and social contingencies - in their success. Politically, the discourse of meritocracy, and especially in the context of a failed meritocracy, 
is corrosive of any sense of social solidarity. As experienced from below, the hubris of meritocratic elites becomes 'the politics of humiliation' and favourable ground is created for a populist reaction as - to repeat Markovits's telling phrase, 'a natural and even apt reaction to extreme meritocratic inequality', evident in economic conditions but also, and if anything more damagingly, in status relations. At this point the argument does of course move back to the empirical plane, and the question arises of what evidence there is that could underpin the connection between problems of meritocracy and populism that is being claimed.

We have sought to address this question, distinguishing two links in the chain of argument: that between status discontents and support for populism and that between such discontents and the failed practice but continuing discourse of meritocracy. As regards the first link, recent research provides rather strong indications that it does indeed exist. Several studies, covering now a wide range of Western nations, show that populist movements and parties are better understood as expressions of status rather than of class politics. Populism finds its strongest support among men and women holding perhaps different class positions but located together towards the base of the status hierarchy, and who are thus largely separated in their social lives, as also in their sociopolitical attitudes, from the cognitive elite in higher level managerial and professional positions. As regards the second link, the available support is less strong, coming from a single study based on focus groups. But what emerges from this study would seem much in line with the idea that among those who have evidently not benefited from the operation of a supposed meritocracy, there exists a strong sense of resentment against, and division from, those who have done so. And in particular insofar as the latter are seen as taking their educational and subsequent attainments as a basis for expressing their social superiority and disparaging their inferiors. 
Research designed to show whether what is here suggested can be further substantiated would be of obvious academic interest. But what is important to note is that it could also be of more than academic consequence. This is so because if what Markovits, Sandel and Goodhart maintain is borne out, an important implication follows. Populism can no longer be understood simply as a reaction against what could be regarded as ineluctable processes of globalisation and technological advance. It would also, in the US and UK at least, have to be seen as a reaction against a main line of policy - the whole project of creating an education-based meritocracy - which, in only slightly differing versions, has been taken up by mainstream parties of the left and right alike. The key motivating idea behind the project, as often openly expressed by its proponents, is that the problem of inequality of condition can best be resolved through increasing equality of opportunity, and of educational opportunity in particular, and thus promoting social mobility. Or, one might say, in the ironic phrase attributed to R. $H$. Tawney, the aim is to create a greater equality of opportunity to become unequal - albeit with the added belief, or hope, that the inequality that results might be regarded as legitimate because merited via educational attainment.

Insofar, then, as such a pursuit of meritocracy is found to have unintended and unwanted consequences in creating favourable ground for populist politics, some fundamental reorientation of policy could appear to be called for. However, what has to be further recognised is that neither the specific ends at which such a reorientation is to be aimed nor the means of its realisation in practice are readily apparent. As Markovits, on reflection, has remarked (2021: 145), 'it is one thing to see that the incumbent order has gone wrong and quite another to know how to build a replacement.' 
In this connection, it is important to note that neither Markovits nor Sandel and Goodhart seek to reject selection by merit per se - in which level of formal qualifications would have to play a major part. They accept that such selection is necessary for social positions and roles where specialised knowledge and relevant competencies have to be guaranteed: no one would wish to have the services of an unqualified surgeon. Moreover, where selection is made by merit, appropriately defined, and independently of social origins, not only is fairness served but at the same time societal efficiency is increased by preventing what could otherwise be a serious wastage of talent.

It is then primarily these points that are reasserted by those who would still seek to uphold the idea of meritocracy - a notable recent example being Wooldridge (2021) and see also, in direct response to Sandel, Song (2021). Their position rests on a distinction made between meritocracy in its true form, which presumably existed at some time in the past, and what Wooldridge (2021: ch. 15) refers to as its subsequent 'corruption'. But the distinction is sociologically naïve. Wooldridge takes as examples of such corruption the ability of wealthy parents to find 'clever ways' of buying educational privilege for their children, or the 'new nepotism' that works through family 'contacts and connections'. However, given that, as he indeed recognises (2021: 311), it is a basic human instinct for parents 'to do the best they can' for their children, what he sees as practices that are corruptive of meritocracy have, rather, to be regarded as its inevitable concomitants. ${ }^{12}$

12 It is indicative of Woolridge's rather slanted views that he also sees meritocracy as having been corrupted, in the British case at least, by the ideologically driven replacement of selective grammar schools by comprehensives, which, he claims, has reduced working-class children's chances of upward social mobility. But this claim is without foundation. Research into this issue (see e.g. Boliver and Swift, 2011; Buscha et al., 2021) has found that the introduction of comprehensive secondary schooling had little effect on social mobility, one way or the other. Grammar schools were indeed engines of working- 
In the light of the foregoing, what would then be involved in attempting to move on from the supposed, but failing, meritocracy of the present day? We may in fact revert to the same three authors with whom we started out for statements, in turn, of the basic problem that arises, of the kind of end state that could be thought in principle to constitute a solution to this problem, but, finally, of the difficulties attendant on reaching such a state.

Following Goodhart (2020:7), the basic problem can be stated as one that turns not on the distinction between true meritocracy and a corrupted version, but rather on that between a society in which meritocratic selection occurs, insofar as it is actually required, according to strictly relevant criteria, and a society in which structures of social inequality pervasively reflect - and in extreme form - what is taken to represent merit, though often very disputably so. Under what conditions could we have the one without the other?

Sandel sees the solution as lying in a rejection of the idea that equality of opportunity, as regulated by some conception of merit, is the best means of mitigating inequality of condition. Rather, a greater equality of condition is necessary to mitigating the unwanted consequences of meritocratic selection as this extends beyond its proper form and limits. He speaks (2020: 224) of the importance of creating 'a broad equality of condition that enables those who do not achieve great wealth or prestigious positions to live lives of decency and dignity developing and exercising their abilities in work that wins social esteem, sharing in a widely diffused culture of learning, and deliberating with their fellow citizens about public affairs'. And central here, from a policy standpoint, must be a critical consideration of what are to count

class mobility but their counterparts, the secondary modern schools, were no less powerful engines of working-class immobility. 
as valuable contributions to the common good - and their appropriate rewards - and especially so, 'where market verdicts miss the mark' (2020: 214).

Markovits, however, points to an underlying difficulty in this position. He observes that market valuations have a distinctive function. They serve to provide 'a measure of the good of all that saves society from the need to reach agreement on the common good': they 'commensurate disagreements about value without needing to resolve them' (2021: 145). In contrast, Sandel's proposed 'new politics of the common good' must lead directly to value conflicts. As Sandel himself recognises (2020: 214), 'the common good is inescapably contestable'. If any significant change is to come, these value conflicts will then have to be fought out in the political arena, and there is no guarantee of any positive resolution. The interests of those in the meritocratic elite lie in the status quo, and they will be resistant to its reconstitution.

In sum, Markovits agrees with Sandel - and also, one could say, with Goodhart - that in fact 'the jig is up', that 'rising meritocratic inequality undermines the credibility of market measures of value' because labour markets are now so constructed as to give prime value to the 'the training and skills that only elites can afford to get' (2021: 144). But what can be expected to follow? The clear possibility exists of political stasis and of the persistence of conditions under which populist reactions to meritocracy as it now exists will continue to represent the main expression of dissent and resistance. 


\section{REFERENCES}

Bloodworth, J. (2016), The Myth of Meritocracy. London: Biteback Publishing.

Boliver, V. and Swift, A. (2011), 'Do comprehensive schools reduce social mobility?, British Journal of Sociology, 62: 89-110.

Bovens, M. and Wille, A. (2017), Diploma Democracy: The Rise of Political Meritocracy. Oxford: Oxford University Press.

Bukodi, E. and Goldthorpe, J. H. (2019), Social Mobility and Education in Britain: Research, Politics and Policy. Cambridge: Cambridge University Press.

Bukodi, E., Dex, S. and Goldthorpe, J. H. (2011), 'The conceptualisation and measurement of occupational hierarchies: a review, a proposal and some illustrative analyses', Quality and Quantity, 45: 623-39.

Buscha, F. Forman, E and Sturgis, P. (2021), Selective schooling has not promoted social mobility in England. IZA Discussion Paper, No. 14640.

Carella, L. (2021) 'The Status of Status: A Review of Contributions to the Literature on Social Status in Political Science. Unpublished manuscript.

Carella, L. and Ford, R. (2020), 'The status stratification of radical right support: Reconsidering the occupational profile of UKIP's electorate', Electoral Studies, 67, 102214.

Chan, T.-W ed. (2010), Social Status and Cultural Consumption, Cambridge: Cambridge University Press.

Chan, T.-W. (2019), 'Understanding cultural omnivores: social and political attitudes', British Journal of Sociology, 70: 784-806.

Chan, T.-W. and Goldthorpe, J. H. (2004), 'Is there a status order in contemporary British society? Evidence from the occupational structure of friendship', European Sociological Review, 72: 512-32.

Chan, T.-W. and Goldthorpe, J. H. (2007), 'Class and status: The conceptual distinction and its empirical relevance', American Sociological Review, 37: 355-71.

Chan, T.-W., Henderson, M., Sironi, M. and Kawalerowicz, J. (2020), 'Understanding the social and cultural bases of Brexit', British Journal of Sociology, doi: 10.1111/1468-4446.12790.

Ehrenreich, B. (1989), Fear of Falling: The Inner Life of the Middle Class. New York: Pantheon Books.

Erikson, R., Goldthorpe, J. H. and Portocarero, L. (1979), 'Intergenerational Class Mobility in Three Western Societies', British Journal of Sociology, 30: 415-41. 
Evans, G. (2022), 'What is the subjective social status scale measuring?', Elections Unit, Nuffield College, Oxford.

Evans, G. and Mellon, J. (2016), 'Working class votes and Conservative losses: Solving the UKIP puzzle', Parliamentary Affairs, 69: 464-79.

Evans, G., Heath, A. and Lalljee, M. (1996), 'Measuring left-right and libertarian-authoritarian attitudes in the British electorate', British Journal of Sociology, 47:93-112.

Fieldhouse, E., Green, J., Evans, G., Prosser, C., Schmitt, H. and Vander Eijk, C. (2020), Electoral Shocks: the Volatile Voter in a Turbulent World. Oxford: Oxford University Press.

Ford, R. and Goodwin, M. (2014), Revolt on the Right: Explaining Support for the Radical Right in Britain. London: Routledge.

Ford, R. and Goodwin, M. (2016), 'A different class? UKIP's social base and political impact: A reply to Evans and Mellon', Parliamentary Affairs, 69: 480-91.

Frank, R. H. (2016), Success and Luck: Good Fortune and the Myth of Meritocracy. Princeton: Princeton University Press.

Gest, J., Reny, T. and Mayer, J. (2018), 'Roots of the Radical Right: Nostalgic Deprivation in the United States and Britain', Comparative Political Studies, 51: 1694-1719.

Gidron, N. and Hall, P. (2017), 'The politics of social status: Economic and cultural roots of the populist right', British Journal of Sociology, 68: S57-S81.

Gidron, N. and Hall, P. (2020), 'Populism as a problem of social integration', Comparative Political Studies, 53: 1028-59.

Goldthorpe, J. H. (2012), 'Back to class and status: Or why a sociological view of social inequality should be reasserted', Revista Española de Investigaciones Sociólogicas, 137: 1-16.

Goldthorpe, J. H. and Jackson, M. (2008), 'Education-based meritocracy: The barriers to its realization' in A. Lareau and D. Conley eds., Social Class: How Does it Work? New York: Russell Sage Foundation.

Goodhart, D. (2020), Head Hand Heart: The Struggle for Dignity and Status in the $21^{\text {st }}$ Century. London: Allen Lane.

Halsey, A. H. (1977), 'Towards meritocracy? The case of Britain' in J. Karabel and A. H. Halsey eds., Power and Ideology in Education. Oxford: Oxford University Press.

Hechter, M. (2004), 'From class to culture', American Journal of Sociology, 110: 400-45.

Hochschild, A. R. (2016), Strangers in their own Land. New York: New Press. 
Inglehart, R. and Norris, P. (2017), 'Trump and the populist authoritarian parties: The Silent Revolution in reverse', Perspectives on Politics, 15: 443-454.

Lareau, A. (2003), Unequal Childhoods. Berkeley: University of California Press.

Littler, J. (2018), Against Meritocracy: Culture, Power and Myths of Mobility. London: Routledge.

MacNamee, S. J. and Miller, R. K. (2009), The Meritocracy Myth. Lanham: Rowman and Littlefield.

Markovits, D. (2019), The Meritocracy Trap. London: Allen Lane.

Markovits, D. (2021), 'The common good or the good of all? Comment on M. Sandel's The Tyranny of Merit', American Journal of Law and Equality, 1: 139-45.

Mattinson, D. (2020), Beyond the Red Wall, London: Biteback Publishing.

Merton, R. K. (1957), Social Theory and Social Structure, ch. 10. Glencoe: Free Press.

Nolan, B and Weisstaner, D. (2020), 'Rising income inequality and subjective social status: the nuanced relative status decline of the working class since the 1980s', Institute for New Economic Thinking and Department of Social Policy and Intervention, University of Oxford.

Norris, P. and Inglehart, R. (2019), Cultural Backlash: Trump, Brexit and Authoritarian Populism. Cambridge: Cambridge University Press.

Oesch, D. and Vigna, N. (2021), 'A decline in the social status of the working class? Conflicting evidence for 8 Western countries, 1987-2017', Comparative Political Studies, doi. 10.1177/00104140211047400.,

Richards, L., Heath, A. and Carl, N. (2020), 'Not just "the left behind"? Exploring the effects of subjective social status on Brexit-related preferences', Contemporary Social Science, doi.org/10.1080/21582041.2020,1847312.

Ridgeway, C. J. (2014), 'Why status matters for inequality', American Sociological Review, 79 : 1-16.

Sandell, M. J. (2020), The Tyranny of Merit: What's Become of the Common Good? London: Allen Lane.

Song, S. (2021), 'Diagnosing democracy's discontent. Comment on M. Sandel's The Tyranny of Merit', American Journal of Law and Equality, 1: 111-6.

Weber, M. (1922/1968), Economy and Society. Berkeley, University of California Press.

Young, M. (1958), The Rise of the Meritocracy, 1870-2033. Harmondsworth: Penguin. 
Young, M. (1994), Introduction to The Rise of the Meritocracy, American edition. New Brunswick: Transaction.

Young, M. (2001), 'Down with meritocracy', The Guardian, June 28.

Young, M. (2006), 'Looking back on Meritocracy' in G. Dench, ed., The Rise and Rise of Meritocracy. Oxford: Blackwell. 
FIGURES 
FIGURE 1: The effects of social status and social class ${ }^{(a)}$ on Left-Right ${ }^{(b)}$ and Libertarian-Authoritarian ${ }^{(c)}$ attitudes $^{(\mathrm{d})}$

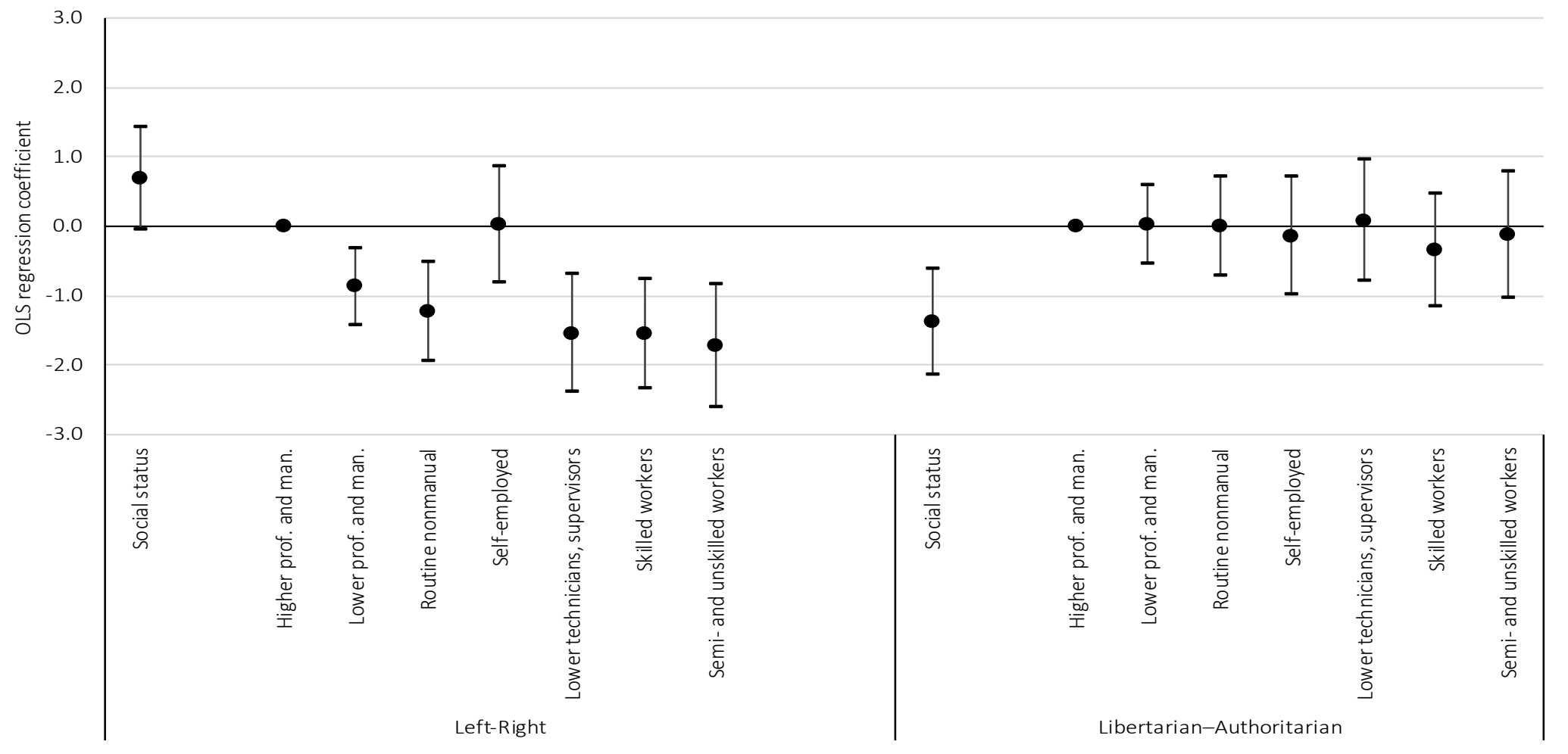

Notes

(a) Reference category: higher-level professionals and managers, large employers.

(b) The values of the left-right scale range from 5 to 25 , with higher values denoting more right-wing views.

(c) The values of the libertarian-authoritarian scale range from 6 to 30, with higher values denoting more authoritarian views.

(d) Other variables in the model: gender, age, education, income.

Source: Chan and Goldthorpe (2007) 
FIGURE 2: The effects of social status and social class ${ }^{(a)}$ on electoral support for UKIP versus all other parties, prior to the EU Referendum of $2016^{(b)}$

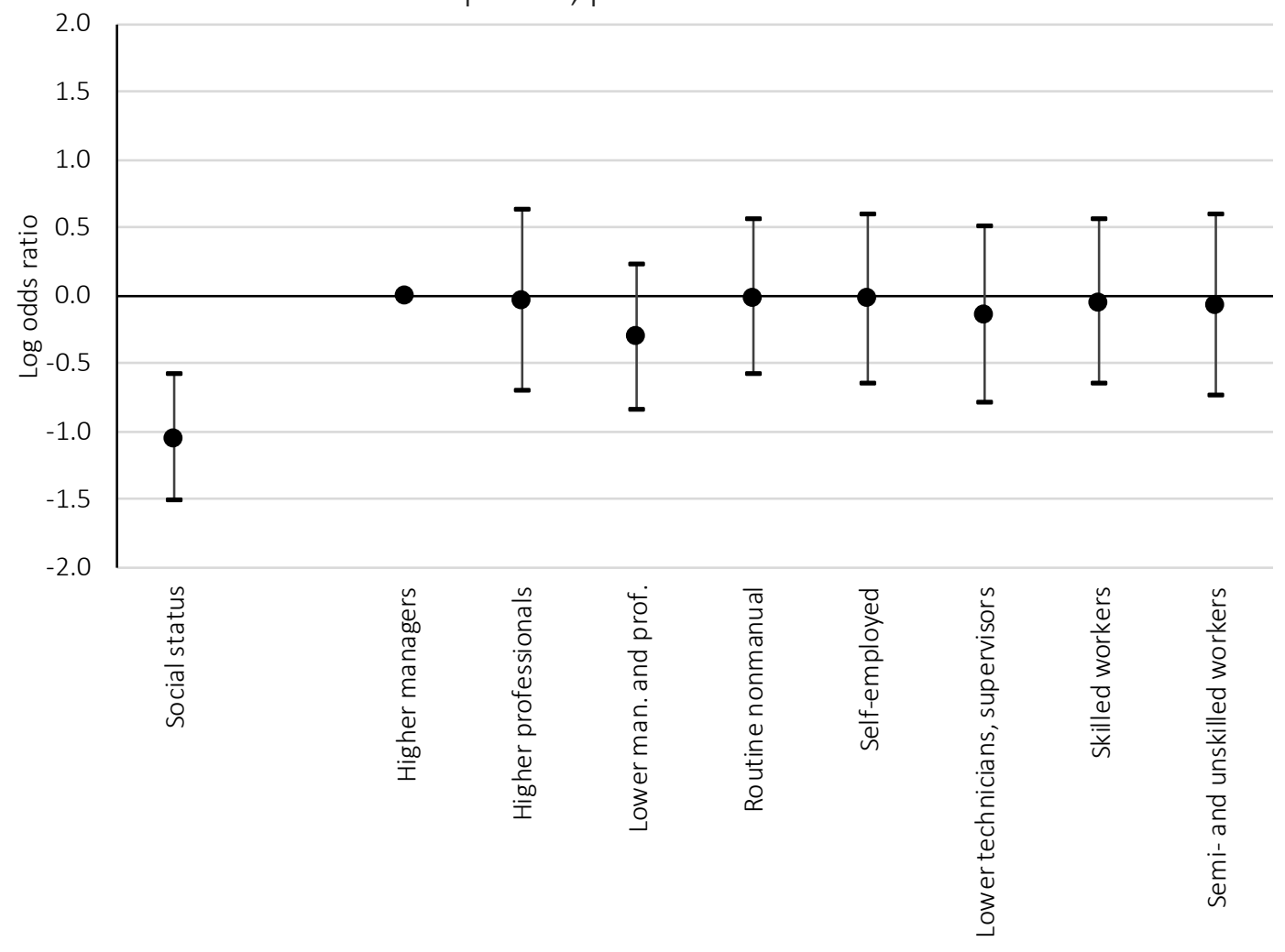

Notes

(a) Reference category: higher-level managers, large employers.

(b) Other variables in the model: gender, age, ethnicity, education, income, region.

Source: Carella and Ford (2020) 
FIGURE 3: The effects of social status and social class ${ }^{(a)}$ on support of Brexit ${ }^{(b)}$

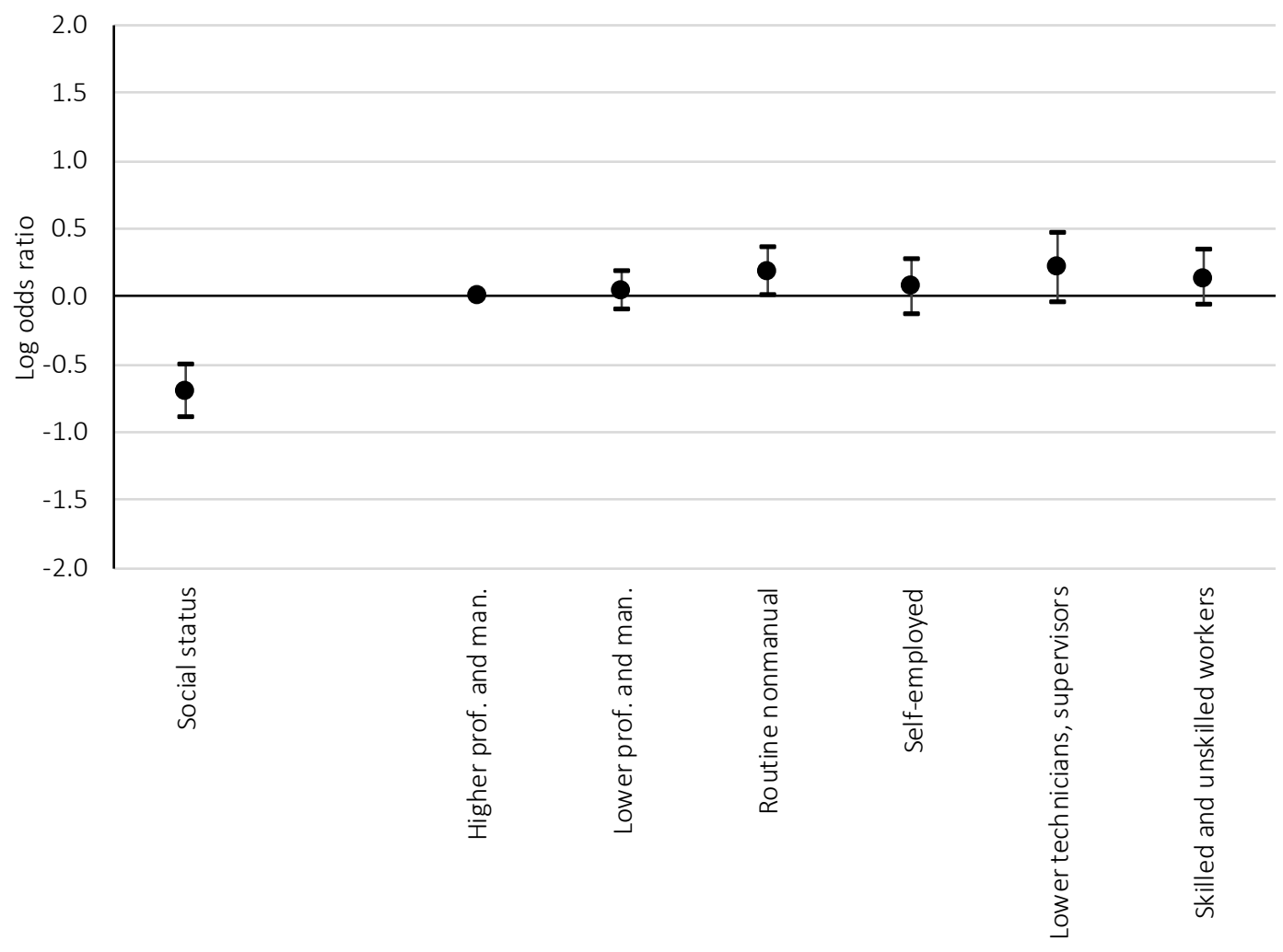

Notes

(a) Reference category: higher-level professionals and managers, large employers.

(b) Other variables in the model: gender, age, ethnicity, education, income, region, marital status, number of children.

Source: Chan et al. (2020) 
ApPEndices 


\section{APPENDIX 1.1}

The Chan-Goldthorpe social status scale: the 31 occupational categories ranked by status score and representative occupations for each category

Rank

Higher professionals : doctors, lawyers, clergy, chartered accountants

Associate professionals in business : brokers, investment analysts, journalists, designers

Specialist managers : financial managers, computer systems managers, personnel managers

Teachers and other professionals in education : teachers, lecturers, school inspectors, education officers

General managers and administrators : general managers in industry, bank and building society managers, national and local government officers

Associate professionals in industry: computer analysts and programmers, quantity surveyors, vocational and industrial trainers

Engineers and technologists : engineers, industrial chemists, clinical biochemists, software analysts

Filing and record clerks : conveyancing clerks, computer clerk, library assistants

Managers and officials not elsewhere classified : security managers, safety managers

Administrative officers : Clerical officers in national and local government, administrative assistants

Numerical clerks : accounts assistants, bank clerks

Associate professionals in health and welfare: nurses, community workers, youth workers

Secretaries : personal assistants, receptionists, word processor operators

Other clerical workers : commercial and clerical assistants

Sales representatives: buyers, technical sales representatives, commercial travellers

Childcare workers : educational assistants, nursery assistants

Managers and proprietors in services : hoteliers, catering managers, publicans, shopkeepers

Plant and site managers : clerks of works, maintenance managers, transport managers

Sales workers : sales and shop assistants, check-out operators, window dressers

Health workers: ambulance staff, dental nurses, nursing auxiliaries 
Personal service workers : caretakers and housekeepers, travel attendants, barbers and hairdressers

Protective service personnel : fire service personnel, police officers, security guards

Routine workers in services : postal workers, car park attendants, hotel porters, couriers

Catering workers: cooks, waiters, counter and bar staff

Store and dispatch clerks : storekeepers, dispatch and production control clerks,

Skilled and related manual workers, not elsewhere classified :

printers, textile workers, woodworkers

Transport operatives : train, lorry, bus and taxi drivers

Skilled and related manual workers in construction and

maintenance : bricklayers, electricians, painters, telephone

repairmen

Skilled and related manual workers in metal trade : fitters, setters, turners, sheet metal workers

Plant and machine operatives: assemblers, machinists, moulders, food processors, canners and packers

General labourers : agricultural workers, factory labourers, goods porters, refuse collectors 
APPENDIX 1.2

The EGP class schema

I Higher-level professionals and managers, large employers

II Lower-level professionals and managers, higher-level technicians, supervisors of nonmanual employees

III Routine nonmanual employees

IV Small employers and proprietors, self-employed workers

$\checkmark \quad$ Lower-level technicians, supervisors of manual workers

VI Skilled manual workers

VII Semi- and unskilled manual workers 